\title{
The Profile of Micro Small Medium Enterprises at The Monetary Crisis Era in1997-1998 Case Study: Intako Sidoarjo
}

\author{
$1^{\text {st }}$ Nasution \\ History Education Departement \\ Universitas Negeri Surabaya \\ Suarabaya, Indonesia \\ email: nasution@unesa.ac.id
}

\author{
$2^{\text {nd }}$ Agus Trilaksana \\ Education History Departement, \\ Universitas Negeri Surabaya \\ Suarabaya ,Indonesia \\ email: agustrilaksana@unesa.ac.id
}

\author{
$3^{\text {rd }}$ Artono \\ Education History Departement \\ Universitas Negeri Surabaya \\ Suarabaya, Indonesia \\ email: artono@unesa.ac.id
}

\begin{abstract}
The purpose of this study is to analyze the acquisition of capital, development of production and marketing, and strategies undertaken by INTAKO in order to survive when the monetary crisis hit Indonesia in 1997-1998. To support this research, we used qualitative descriptive method. The study was conducted from April 2017 to November 2017. The results showed that the capital used by MSME's came from private funds as well as domestic loans. Production of goods is adjusted to existing demand and marketed through available networks. In addition, the strategy undertaken to enable INTAKO to survive in the midst of the crisis is to improve the quality of production and reduce its quantity, and by using raw materials from shoe factory owners outside of INTAKO which is out of business due to the monetary crisis. Based on the results of this study, it can be concluded that MSME's are still able to survive and not affected by the monetary crisis that hit Indonesia in 1997-1998. This is because the capital of MSME's is not affected by the rupiah exchange rate weakened during the monetary crisis. In addition, MSME's also produce goods in accordance with existing orders, so that the goods produced will be sold out. This means, MSME's can survive in the midst of monetary crisis and can be used as a solution to support the economy, especially in Indonesia
\end{abstract}

Keywords: MSME's, Monetary Crisis, INTAKO.

\section{INTRODUCTION}

The biggest crisis of monetary that attack the Asian region in 1997 was due the failure of crony capitalism policy. [1] According to Krugman [2], the businessmen that built their own empire by relying on close relations to the government bringing on the credit expansion does not develop and distend that makes severe crisis. On the other side, the monetary policy in the form of liberalization financial market by ignoring the rule as basic reference became trigger factor for the 1997 crisis.

The first crisis occurs in Thailand and spread on the others Asian countries, included Indonesia. In Indonesia, the crisis happened because the weakening of the Indonesian rupiah exchange against the US dollar. The exchange rates that suddenly increase make some investors and businessmen nervous in perceiving which is caused on the losses on high capital especially in US dollars and much rush. The weakness of rupiah exchange rate as whole had an impact on the weakness of the Indonesian economy. It is affected into several sectors such as banking, the real sector and other sectors that make the government publish policies to control it. The policies are tightened liquidity, structural adjustment through trade and investment liberalization, as well as restriction on landing to the property sector and widening the range of exchange rate intervention. Some policies that aim to save the Indonesian economy has not succeeded yet, what has happened is the opposite side which is the condition of Indonesian economy getting worse?

Different with the big industry, the Micro Small Medium Enterprises (MSME's) in Indonesia showed their strength to the monetary crisis in 1997/1998. Some sectors of the society business owners are still going well, even become one of the pillars of the national economy. During the crisis era, MSME's in Indonesia were able to survive and increase the progress.

One of the MSME's in Indonesia can survive and still exist is the industry of a bag and suitcase (INTAKO) in Sidoarjo. In 1986 INTAKO collaborated with PT. Garuda in producing bag of pilgrims. That's why INTAKO is widely known by the society and got some awards.

Therefore, the researcher wants to examine more deeply about "The profile of micro small medium enterprises at the monetary crisis era in 1997-1998 case study: INTAKO Sidoarjo". The study focused on how to obtain the capital and development of production and marketing, and how the strategy undertaken by INTAKO in surviving in the midst of monetary crisis attack Indonesia in 1997/1998.

The research which related to MSME's has been widely carried out both national or international. The research in Indonesia includes [3] which discuss about the Evaluation of INTAKO Cooperative empowerment model on MSMEs at Tanggulangin Sidoarjo the center of bag and suitcase Industry as Poverty Prevention Efforts. This research uses the center approach or clustering for development MSME's. The result of the research indicates that there is a need some modify for programs that have been carried out by INTAKO cooperative as development for its member. It be expected that the modification become a poverty prevention effort for Micro entrepreneurs.

The next research related to the survival of MSME's from the crisis attack in a country has also been carried out by [4] titled "Small and Medium Enterprise Dynamics in Indonesia". The purpose of the research is to know the development of big or small industry in Indonesia before and during the crisis which is using the theoretical frame work to show the work of several mechanisms such as the existence of technology through consumers and contractors aboard. The result shows those SMEs (Small Medium Enterprises) or SME's are more able to face the crisis when compared to big companies. This research also reports that urban areas are more affected than rural area. This is due to the high 
population density in urban area as consequence higher economic difficulties.

Among these researches, it is focused more on the condition of MSME's INTAKO during monetary crisis in the $1997 / 1998$ and the research will be taken into consideration as a material for analysis the research.

\section{RESEARCH METHODS}

This research uses qualitative descriptive method by doing interview to entrepreneur and some personal from the related institution. The collected data from this research is the result of interview between the researcher and the informant. The research focused on the description the process of empowerment small industries Tanggulangin by the government, in this case as the implementing agency of the cooperative, MSME's, and trade of Sidoarjo regency as the entrepreneur of bag and suitcase.

The research takes place at Kendansari Tanggulangin, Sidoarjo in April until November 2017. The informant in this research is a manager INTAKO Tanggulangin Sidorajo and as local society. There are several informants through the research:

\section{1) Diskoperindag party}

a) Yayuk P. Rahayu, SH, MH

(As the Head of Industry Division of the Cooperatives official, MSME's, Industry, Trade and Energy of Mineral Resources of Sidoarjo Regency)

b) Moh. Amin (As Staff of the Trade Division of the Cooperative official, and Energy of Mineral Resources of Sidoarjo Regency)

c) Badriyono, SE (As Staff of the Trade division of the Cooperatives official, MSME's, Industry, Trade and Energy of Mineral Resources of Sidoarjo Regency)

2) The craftsmen of bags and suitcase.

a) Mrs. Titis As Head of the General division of the INTAKO Cooperative as well as craftsman of a bag and suitcase. The reason why the researcher chose Mrs. Titis was able to explain how empowerment was carried out by the Department of Cooperatives, MSME's, Industry, Trade, and Energy of Mineral Resources to the Tanggulangin Suitcase Industry (INTAKO) located in the Kedensari village.

b) Mr. Nuryono and Mr. Haroni Effendy as a craftsman of Tanggulangin bags and suitcase. The reason the researcher added Mr. Nuryono and Mr. Haroni Effendy in the informants were to strengthen the interview results

c) Mrs. Tia as personnel in INTAKO and as the scraftman of the bag and suitcase.

d) H. Abdul Mughnig. $\mathrm{Z}$ as a head of Kendensari village and as the craftsman of the bag and suitcase.

e) Mr. Nur as an employee of the INTAKO Cooperative.

f) Mr. Sholahuddin as the manager and advisor of INTAKOCooperative.

\section{RESULTS AND DISCUSSION}

The success of Indonesian economic development after the crisis era depends on the ability in realize "the development that truly to people-oriented", because the crisis happened in Indonesia in 1997 which is caused to several sectors bankrupt, raw materials increased, the rupiah exchange rate declined, the banking sector slumped that influenced to the industrial sector in the term of capital, resulting in the position of business actors changing. But, different with MSME's that still exist and become a key of safeguard of the national economic at the crisis era, moreover it can be used as a driver of economic development after the crisis. MSME's or cooperatives are chosen as representation of people's economic because in addition to absorbing around 90 percent of the workers, and then give more value around 56 percent where the agricultural sectors play as important role (around 70 percent). Besides, this was evidenced by the growth of Gross Domestic Product (GDP) from 1997-2003.

\section{A. Funding Capital Resources}

The capital is based on the individual fund and financing from borrowing from the bank. The craftsman starts the business as small craftsmen who only as bulk labors and get small commission. After felt their ability, the small craftsman began to dare to accept the orders for bag and suitcase. To establish their own business the craftsman uses their own money start from Rp. 60.000,- Rp. 1000.000. at that time for the bag they sale only Rp. 50.000 and for the suitcase Rp. 150.000,- Rp. 200.000,. the prices are set depends on the material and complexity of making the bag and the suitcase its self. [5]

Based on the result of an interview with one of the craftsman regarding the monthly turnover of the bag and suitcase during the crisis era (1999), it could reach between Rp. 1.000.000,- Rp. 15.000.000,. depends on how much the orders. If the craftsman gets many orders from the consumer, the resulting turnover can reach Rp. 40.000.000 per month. [5]

\section{B. Production sector}

In 1997, there was a regulation from the government about the business license, in this year INTAKO registered their self to buy a land which is used as showroom, before the showroom INTAKO was placed one of the member's houses. The fund for this showroom is obtained from membership fees and borrow from the bank. Previously, INTAKO and the craftsmen in Tanggulangin only made large-size suitcase with the Panama brand, but after that there was as industrial expansion to make some innovations such as bag and shoes. Since its establishment in 1976, INTAKO always growth insignificantly.

According to the interview with Mrs.Titis on 27 November 2017, INTAKO experiencing the big time in 1986-2000. This was strengthened by her statement:

' 'in 1987 INTAKO received the orders from Garuda for pilgrim's bag in Indonesia. This collaboration only lasted 3 years. The tender winner is one of the craftsmen who is the 
members of INTAKO cooperative. To fulfill the orders, all levels of society in Tanggulangin become a part of making the product from the housewife until pedicab driver. On order the suitcase for pilgrims brings great profit for economic of Tanggulangin".

It was during the 1997-1998 crisis period, when the Indonesian economy gets shakiness which is impact to bounced up the raw material and many businesses get bankrupt, but INTAKO was able maintain their existence. According to Mr. Tohir this crisis had no impact on reducing the products. In this year 1997 there was many orders from the various agencies for seminar.

In 1997-1998 the business of Mr. Tohir was developed by continuing to produce the bag based on the orders and lump sum. The product that Mr. Tohir made is bag for seminars, if he gets order and imitation bag from famous brand in the world. The material which used to produce the bags are shipped from Surabaya especially at Keramat Gantung. The raw material is not original leather but imitation leather, Mr. Tohir stated that in 1997/1998 there is no craftsmen can have made a bag from leather. Many orders from seminars and order in big number makes the producing bag and suitcase still going on even in crisis era

Mr. Khoirul stated that when the crisis era, the bag producing runs well and does not find any obstacle, production of the product based on order from institutions demand. The marketing through many other ways such as government, private companies, and universities so that the order of product still in high number while in crisis era.

According to Mrs Titis, at the crisis era in 1997/1998 the condition of the products does not decrease, because sales and the order which receive is high, moreover the product's price is very expensive at that time. Many order receive with the imitation material with the price is low does not impact to the operational production, it is also supported by craftsmen fee is constant. Even in crisis era it doesn't impact to the production of bag and suitcase in Tanggulangin.

The craftsmen of the leather bag in Tanggulangin do not need a specific location to carry out the production process. These craftsmen made the product in their house, they provide one or two room for produce the bag. The advantages of the industrial location in Tanggulangin easily to make coordination and cooperate with other entrepreneurs. With a good cooperation, the entrepreneurs will be able to regulate prices, both products and raw materials, doing the marketing or promotion together that are more effective, and also cooperation in developing the quality of their products.

\section{Marketing}

Through the literature review in this research, it was obtained an illustration as the location that produces and markets the products of bags and suitcases and other equipment, Tanggulangin has accommodated up to 6.000 workers and able to supply up to 70.000 units of product every month. In this quarter, there are 325 units of showrooms, which sell craft bags and suitcases where every month can reach up to 5 billion. [6]

The orders are very influential to marketing aspect. Before the crisis era in 1997-1998, the market orders for leather products from Kedensari village are too much. The orders are only come from domestic market but from foreign country. This is evidenced by the development of INTAKO which managed to establish cooperation with Garuda Indonesia for the production of pilgrim bag from 1986 to 1990 [5] besides, the development of INTAKO cooperative business before the monetary crisis, INTAKO carried out business flexibility by establishing subsidiaries with special objective and production, for example to produce YMPI instrument bag from Japanese and beauty bag from PT Eres Revco and Indian Air. [5]

At the beginning of the monetary crisis in 1998, Sentra INTAKO got a lot of benefits from the orders request from Kalimantan, Sumatra, and Sulawesi which who become resellers of INTAKO products. There are so many resellers from outside Java made INTAKO glorious in 1998 at crisis era.

The bag leathercraft needs hand skills and tenacity. For the craftsman in Tanggulangin believed with the phrases "nothing can't be made by Tanggulangin craftsman". This is because the ability of Tanggulangin craftsman in making the leather bag is not in doubt. The craftsman often collects the world fashion magazine for references the model of leather bag. From looking the picture, they are able to produce the product same as like the picture [7]. With the various result of the product and following the trend, the supply price from INTAKO will be easier because there are many outlets in marketing INTAKO products.

The INTAKO center also provide an opportunity for consumer for choosing the model of the product that they want. This is one of the ways for attract the consumer for the product from INTAKO center Kedensari. Based on research from [8] the consumer who want a different model, can make their own designs or provide example of product that they have to craftsman in Kedensari, and then the craftsman will make based on the costumer taste.

The minimum numbers of the orders are unlimited. This is because the characteristics of the production price are mostly variable cost. If the order is small, the price per product item becomes a little more expensive.

The products of leather bag have a big chance and market opportunity until now. Research from [8] found that to create new market opportunities, the craftsman in Kendensari also often held the events aimed at introducing their products to customers, in the form of promotion using brochures, or the internet, joint exhibitions, or through cheap market exchanges Tanggulangin products such as Eid fair and also shopping fairs to commemorate national days like Independence Day.

The marketing of the leather product in Tanggulangin is generally divided into two rows. Firstly, are direct sales, like through shop, counter at Tanggulangin or agents from the concerned businessmen. Secondly, is through the orders. Based on the research from [8] for direct sales is less profitable because it does not sell well, the biggest turnover is from the orders.

The marketing process starts from the consumer choices. The consumers in this case are ordering one of the product design or their own designs then order the product to the craftsman. If the order in big number, then the craftsman 
will make the model first and then give it to the consumer to see the result. If the consumer does not like the result of the product, the craftsman will make a contract to finish the orders.

In choosing the brand, the ordering can choose the brand from the craftsman (some craftsman has their own brand patented), without brand or the consumer can use their own brand. The product that has been finished can take able by the ordering or can be delivered by the craftsman. The postage can be borne by the consumer or charged to the cost of production [8].

The current marketing problem that faced by the craftsman of leather bag is the reduced public interest in leather product because the price is relatively expensive. The consumers prefer to choose the product with imitation leather or from a mixture of leather with imitation because the price is cheaper. In general, the problem of small business marketing is an ability to penetrate foreign markets. The industry of leather bag is experiencing the same problem. Whereas INTAKO leather product have entered into foreign market but always through the foreign parties as ordering and also marketers [8]. Using the brand, the ordering from foreign will be detrimental because the name of INTAKO Kendangsari will be difficult to recognize and losses the value that actually should be enjoyed by the leather craftsman.

This problem will be resolved if there are parties who can make directly between leather bag manufactures and foreign markets and promote their product with their own brands. With the constraints of direct access to foreign markets, it is necessary to make collaboration with all the parties to overcome these obstacles and challenges.

\section{MSME's Strategy}

To face various challenges that arise because monetary crisis, MSME's at Kedensari do some changes in order that business activities still exist. The research result from [6] found that mechanism changes are economic activities as effect from monetary crisis causes capital limitations and scarcity the raw materials. Through networks that they created, develop, and use, capital limitations can be solved with creative production activities by reduce quantity and increase quality of stuffs. The scarcity of raw materials in production activities it can be solved with collaborating owned material and utilize sold material by the owner of big shoes factory that bankrupt outside the INTAKO region as monetary crisis effect.

For getting the materials, they use social network from supplier of raw materials, inside or outside INTAKO region [6]. With that strategy, monetary crisis that goes on 1998 felt by them there's no effect, this matter marked by continuing business activities fluently to Kedensari society

MSME's agent who joined in INTAKO cooperatives do the other strategies. [9] said that cooperatives also give protection in order to selling the product price from members because of the price war. The Steps that have been taken by members of cooperatives is doing regular meeting (every three months) for evaluating business development.
The product marketing members of INTAKO cooperatives can be fluent, cooperatives administrators always maintain partnership with domestic bureaucrats and always take care of good relationship with foreign importers.

\section{CONCLUSION}

The research about MSME's profile in monetary crisis in 1997/1998, Case Study: INTAKO Sidoarjo, resulting some conclusion as follows:

Monetary crisis that hit Indonesia in 1997-1998 there's no impact for MSME's, that still exists in the midst crisis era. This is because the most of MSME's producing the product according to exist demand. Besides, capital that be used by MSME's is personal capital and loan capital which is obtained from domestic, so it's not affected by weakened rupiah exchange rates that happened on monetary crisis in Indonesia 1997-1998.

Monetary crisis causes capital limitations and scarcity of raw materials. It can be done by resolving the problems through network that they created, develop, and use. Capital limitations can be handled with creative production activities by reduce quantity and increase the quality of products. Scarcity of raw materials in production activities resolved by collaborating the owned materials and utilize sold raw materials by the big shoe factory owners which bankrupt outside INTAKO region as monetary crisis effect.

With those strategies, monetary crisis that goes on 1998 that felt by them there's no effect, this matter marked by continuing business activities fluently to Kedensari society.

\section{ACKNOWLEDGMENT}

I would like to thank to my colleague, RN Bayu Aji who help for editing and finishing this article.

\section{REFERENCES}

[1] H. Helen, "Crony Capitalism and the East Asian Currency and Financial Crises," vol. 15, no. 3, 1999.

[2] Bjornskov, "Institutions, Entrepreneurship, and Economic Growth: What Do We Know and What Do We Still Need to Know?," J. Acad. Manag. Perspect., vol. 30, 2016

[3] A. A. Dkk, "Evaluasi model pemberdayaan Koperasi Intako pada UMKM di Sentra Industri Tas dan Koper Tanggulangin Sidoarjo sebagai Upaya Pencegahan Kemiskinan,” J. Ekon. Bisnis, 2016.

[4] R. \& S. Berry, "Small and Medium Enterprise Dynamics in Indonesia," J. Bull. Indones. Econ. Stud., vol. 37, no. 3, 2001.

[5] W. Azqiyah, "Koperasi Industri Tas dan Koper (Intako) di Tanggulangin Sidoarjo Tahun 1976-2013," AVATARA, e-Journal Pendidik. Sej., 2016.

[6] M. Adib, "Krisis moneter: jaringan sosial sebagai strategi pada kegiatan industri Tas dan kopor di kawasan intako Jawa Timur dalam menghadapi krisis," scholar, 1999.

[7] B. dan U. Bank Indonesia (Direktori Kredit, "Pola Pembiayaan Usaha Kecil.," 2009.

[8] L. P. P. Indonesia, Profil Bisnis Usaha Mikro, Kecil dan Menengah(UMKM). Bank Indonesia, 2015.

[9] Nurhadi, "Memberdayakan Industri Kecil dengan Koperasi (Suatu Profil Koperasi INTAKO di Sidoarjo Jawa Timur)," $J$. Ekon., 1998 